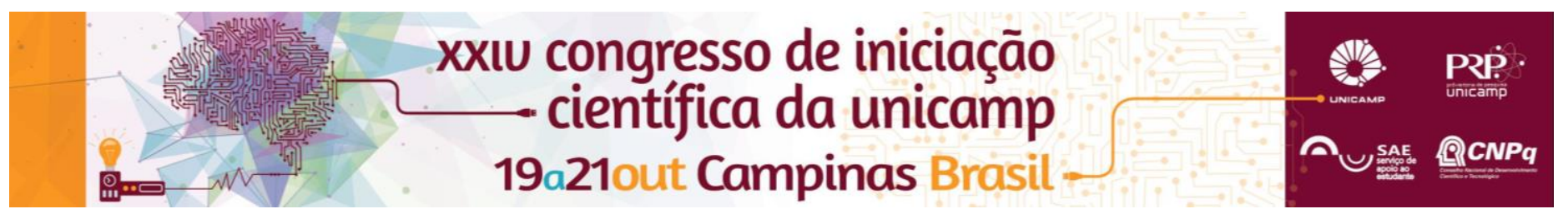

\title{
DANÇA E INCLUSÃO DA PESSOA COM MOBILIDADE REDUZIDA
}

\author{
*Juliana Tiemi Anglas Tarumoto, Mariana Baruco Machado Andraus
}

\section{Resumo}

Neste trabalho, realizou-se a pesquisa de três companhias que possuem em seu elenco bailarinos com e sem deficiência, e paralelamente foi feita a construção de um produto final prático no formato de videodança, ambas as etapas trazendo a reflexão sobre diferentes terminologias que permeiam este tema.

\section{Palavras-chave:}

Dança inclusiva, habilidades mistas, corpos diferenciados.

\section{Introdução}

Henrique Amoedo (2002) foi um dos primeiros a utilizar o termo "dança inclusiva" em sua pesquisa, para se referir aos trabalhos com bailarinos sem e com deficiência, porém, ao apresentar a terminologia, logo expôs a vontade de que "inclusiva" seja um termo provisório. Hoje, 14 anos depois, ainda utiliza o termo, ressignificando, porém, o seu uso.

Este projeto pesquisou três companhias da região Sudeste do Brasil: Cia Dança sem Fronteiras (São Paulo-SP), Pulsar Cia de Dança (Rio de Janeiro-RJ) e Grupo Mão na Roda (Diadema-SP) - esta última atuou durante 16 anos, mas, devido à sua importância no cenário da dança, reconheceu-se a relevância desta para a pesquisa. Todas as companhias possuem bailarinos com e sem deficiência no elenco.

Para a parte prática da pesquisa, realizou-se a produção de um videodança ao lado de uma cocriadora, que tem mobilidade reduzida, que foi o resultado dos laboratórios de improvisação que ocorreram no decorrer da pesquisa.

\section{Resultados e Discussão}

Desde o início da pesquisa, a colocação de Amoedo (2002) de não haver necessidade do termo "inclusiva" seguido do termo dança foi algo que agiu como questão provocadora. Ao longo do tempo, a questão ganhou mais reflexões, que se fortaleceram a partir do contato da pesquisadora com as companhias pesquisadas.

A diretora Teresa Taquechel, da Pulsar Cia de Dança, afirmou que sempre se coloca como diretora de uma companhia de dança contemporânea, já que ela mesma observa que quando o público vai assistir à Pulsar, vai para ver dança, como vão a qualquer outro espetáculo de companhias de dança.

Ainda, Fernanda Amaral, diretora da Cia Dança sem Fronteiras, diz que seu elenco é formado por bailarinos com habilidades mistas, já que cada bailarino tem um potencial a ser explorado, independentemente de existir ou não a deficiência.

No decorrer da pesquisa, chegou-se ao livro "Corpos Diferenciados: a criação da performance 'Kahlo em mim eu e(m) Kahlo'”, de Fernando Henrique Oliveira, no qual o autor constrói o termo "corpos diferenciados" para referir-se a artistas com deficiência.

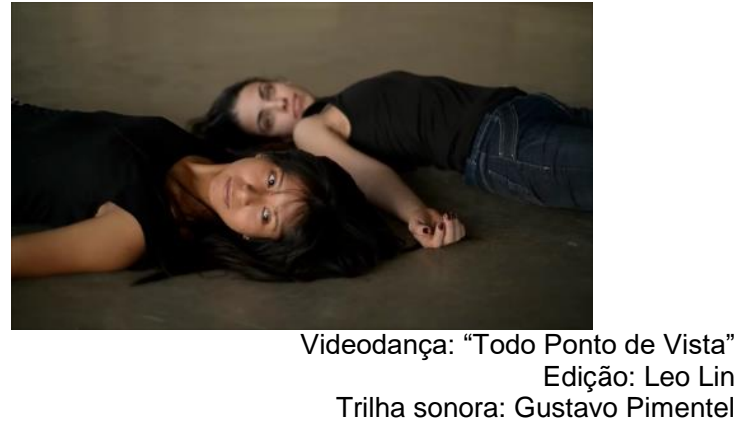

Durante os laboratórios práticos e construção do videodança, essas reflexões também apareceram, já que em nenhum momento os encontros entre pesquisadora e cocriadora ocorreram com o objetivo de relação de professora-aluna, mas sim de parceria. Assim, instaurada essa parceria, foi possível que ambas explorassem suas habilidades a partir de exercícios de improvisação, como por exemplo, exercícios descritos por Andraus (2014).

Junto aos laboratórios práticos, foram se realizando conversas entre pesquisadora e cocriadora, nas quais foram expostos os anseios e mesmo receios vindos da cocriadora, sobre como é estar dançando, já que, até então, dançar era visto como impossível para ela. Segundo seu relato, construir o videodança e se ver dançando foi algo gratificante.

\section{Conclusões}

A pesquisa mostrou como cada vez mais as pessoas com deficiência passam a fazer parte do cenário artístico, devido a suas habilidades e potencialidades, e como ao entender a dança contemporânea como aquela que parte de perguntas, a resposta se mostra nos diversos corpos dividindo a cena.

\section{Agradecimentos}

Agradecimento à Fundação de Amparo à Pesquisa (FAPESP) pela bolsa de Iniciação Científica.

${ }^{1}$ AMOEDO, H. Dança Inclusiva em Contextos Artísticos Análise de Duas Companhias. 2002. 181 p. Dissertação (mestrado em Performance ArtísticoDança). - Faculdade de Motricidade Humana, Universidade Técnica de Lisboa, Lisboa.

${ }^{2}$ ANDRAUS, M. B. M. Arte marcial na formação do artista da cena. Jundiaí: Paco

Editorial, 2014

3 OLIVEIRA, Felipe Henrique Monteiro. Corpos diferenciados: A criação da

performance "Kahlo em mim eu e(m) Kahlo". Maceio: EDUFAL, 2013. 